\title{
PERAN PREFERENSI MEREK DALAM MEMEDIASI HUBUNGAN ANTARA EKUITAS MEREK DENGAN NIAT BELI
}

\author{
I Made Putra Adnyana ${ }^{1}$ \\ Ni Nyoman Rsi Respati ${ }^{2}$ \\ ${ }^{1,2}$ Fakultas Ekonomi dan Bisnis Universitas Udayana (Unud), Bali, Indonesia \\ e-mail: akundananjaya@gmail.com
}

\begin{abstract}
ABSTRAK
Penelitian ini bertujuan untuk menjelaskan pengaruh ekuitas merek terhadap preferensi merek, pengaruh ekuitas merek terhadap niat beli, pengaruh preferensi merek terhadap niat beli, dan peran preferensi merek dalam memediasi hubungan antara ekuitas merek dengan niat beli. Penelitian ini dilakukan di wilayah kota denpasar dengan menggunakan 110 responden. Metode pengumpulan data yang digunakan adalah metode simple random sampling dengan teknik analisis SEM. Hasil penelitian menunjukkan bahwa ekuitas merek berpengaruh positif dan signifikan terhadap preferensi merek. Ekuitas merek berpengaruh positif dan signifikan terhadap niat beli. Preferensi merek berpengaruh positif dan signifikan terhadap niat beli. Preferensi merek sebagai variabel mediasi berpengaruh signifikan secara tidak langsung terhadap niat beli melalui variabel ekuitas merek. Garuda Indonesia perlu memperhatikan loyalitas merek dikarenakan loyalitas merek merupakan satu-satunya unsur equitas merek yang terkait dengan perolehan laba di masa depan. Garuda Indonesia harus lebih meningkatkan preferensi merek perusahaan di benak calon konsumen guna terciptanya niat beli.
\end{abstract}

Kata kunci: ekuitas merek, preferensi merek, niat beli

\begin{abstract}
This study aims to explain the effect of brand equity on brand preference, the influence of brand equity on buying intentions, the influence of brand preferences on buying intentions, and the role of brand preferences in mediating the relationship between brand equity and purchase intentions. This study was conducted in the city of Denpasar with 110 respondents.Data collection method used is simple random sampling method with SEM analysis technique. The results showed that brand equity has a positive and significant effect on brand preference. Brand equity has a positive and significant impact on purchasing intentions. Brand preference has a positive and significant impact on purchasing intentions. Brand preference as a mediating variable significantly indirectly influences purchase intentions through brand equity variables. Garuda Indonesia needs to pay attention to brand loyalty because brand loyalty is the only element of brand equity associated with future earnings gain. Garuda Indonesia should further enhance the company's brand preference in the minds of potential customers for the creation of purchase intentions.
\end{abstract}

Keywords:brand equity, brand preference, purchase intention 
I Made Putra Adnyana, Peran Preferensi MerekMemediasi...

\section{PENDAHULUAN}

Dewasa ini perkembangan jasa transportasi di Indonesia mengalami peningkatan pertumbuhan. Demikian halnya dengan industri penerbangan nasional mengalami pertumbuhan yang tinggi. Hal ini dibuktikan dengan banyaknya maskapai penerbangan seperti, Batik Air, Citilink, Garuda Indonesia, AirAsia, Kalstar Aviation, Lion Air (www.hubud.dephub.go.id). Banyaknya maskapai di Indonesia membuat persaingan dalam industri ini semakin ketat. Persaingandi bisnis penerbangan makin terfragmentasikarena hadirnya pemain pemain swasta dengan permodalan yang cukup dan strategipenetrasi bisnis yang brilian. Khusus munculnya pemain pemain baru yang amat percaya diri dan cukup sukses mengambil positioning sebagai low cost carrier yaitu persaingan melalui perang harga tiket murah.

Banyaknya jumlah maskapai penerbangan yang mampu memenuhi permintaan seseorang terhadap jasa transportasi udara menyebabkan perusahaanperusahaan tersebut harus memikirkan strategi yang mampu membuat diri mereka lebih unggul dari para pesaingnya. Salah satu strategi yang umum digunakan adalah dengan menetapkan merek pada jasa tersebut.Pada saat melakukan keputusan pembelian, konsumen biasanya melakukan perbandingan merek produk yang ingin dibeli. Hal ini dilakukan oleh konsumen untuk dapat memilih produk yang tepat. Perusahaan harus mampu menguatkan merek produknya dalam benak konsumen. Merek menurut Alma (2014:147) Suatu tanda atau simbol yang memberikan identitas suatu barang atau jasa tertentu yang dapat berupa kata-kata, gambar atau kombinasi keduanya. Kunci utama untuk memenangkan persaingan 
adalah memberikan nilai yang kuat pada merek, Iriani (2008) menyebutkan bahwa kekuatan merek terletak pada kemampuannya memikat konsumen untuk membeli produk yang diinginkannya. Merek penting bagi perusahaan untuk menunjukkan nilai produk yang ditawarkan ke pasar.

Ditengah persaingan antar maskapai penerbangan yang semakin ketat, banyak upaya yang dilakukan maskapai-maskapai penerbangan tak terkecuali Garuda Indonesia. Sebagai salah satu perusahaan penerbangan tertua di Indonesia, Garuda Indonesia masih stabil untuk bersaing dengan maskapai penerbangan baru lainnya. Garuda Indonesia yang berdiri pada tanggal 26 Januari 1949 di Jakarta ini merupakan salah satu maskapai penerbangan yang ada di Indonesia yang menyediakan fasilitas mulai dari fitur kabin yang lengkap, hiburan dalam pesawat seperti: Audio and video on demand (AVOD) denganLiquid Crystal Display $(L C D)$ TV layar sentuh hingga internet didalam pesawat dan hidangan khusus yang disediakan oleh Garuda Indonesia (www.garuda-indonesia.com).

Awal perkembangan Garuda Indonesia sampai sekarang ini menjadi jasa penerbangan yang memiliki merek yang kuat ini ditunjukan masuknya Garuda Indonesia ke 10 data airline terbaik menurut SkyTrax. Maskapai Garuda Indonesia berada di urutan ke 10 pada 10 maskapai terbaik didunia tahun 2017 menurut SkyTrax. Untuk menghadapi persaingan yang begitu ketat, Garuda Indonesia harus mempunyai strategi dalam merebut pasar yang sudah ada dan pasar yang masih baru bagi Garuda Indonesia. Berbeda dengan Skytrax menurut Top Brand Indexkategori transportasi airlines bahwa merek GarudaIndonesia 
I Made Putra Adnyana, Peran Preferensi MerekMemediasi...

berada pada posisi pertama tahun 2013-2017(www.topbrandaward.com).Ditampilkan dalam tabel dibawah ini:

Tabel 1.

Data pengguna Maskapai Penerbangan di Indonesia Tahun 2013-2017

\begin{tabular}{|c|c|c|c|c|c|c|c|c|c|c|}
\hline \multirow[t]{2}{*}{ Merek } & \multicolumn{2}{|c|}{2013} & \multicolumn{2}{|c|}{2014} & \multicolumn{2}{|c|}{2015} & \multicolumn{2}{|c|}{2016} & \multicolumn{2}{|c|}{2017} \\
\hline & $\begin{array}{l}\text { TBI } \\
(\%)\end{array}$ & TOP & $\begin{array}{l}\text { TBI } \\
(\%)\end{array}$ & TOP & $\begin{array}{l}\text { TBI } \\
(\%)\end{array}$ & TOP & $\begin{array}{l}\text { TBI } \\
(\%)\end{array}$ & TOP & $\begin{array}{l}\text { TBI } \\
(\%)\end{array}$ & TOP \\
\hline $\begin{array}{l}\text { Garuda } \\
\text { Indonesia }\end{array}$ & 41,2 & $\begin{array}{l}\text { TOP } \\
\text { I }\end{array}$ & 39,6 & $\begin{array}{c}\text { TOP } \\
\text { I }\end{array}$ & 40,0 & $\begin{array}{c}\text { TOP } \\
\text { I }\end{array}$ & 41,9 & $\begin{array}{c}\text { TOP } \\
\text { I }\end{array}$ & 40.7 & $\begin{array}{l}\text { TOP } \\
\text { I }\end{array}$ \\
\hline Lion Air & 30,8 & $\begin{array}{l}\text { TOP } \\
\text { II }\end{array}$ & 32,3 & $\begin{array}{l}\text { TOP } \\
\text { II }\end{array}$ & 35,1 & & 30,5 & $\begin{array}{l}\text { TOP } \\
\text { II }\end{array}$ & 31.8 & $\begin{array}{l}\text { TOP } \\
\text { II }\end{array}$ \\
\hline Citilink & 0,8 & & 2,7 & & 4,4 & $\begin{array}{c}\text { TOP } \\
\text { II }\end{array}$ & 8,9 & & 9.1 & \\
\hline Air Asia & 9,9 & & 10,8 & & 8,7 & & 7,7 & & 6.9 & \\
\hline $\begin{array}{l}\text { Sriwijaya } \\
\text { Air }\end{array}$ & 5,8 & & 4.0 & & 4,4 & & 3,2 & & 3.0 & \\
\hline
\end{tabular}

Keterangan:

TBI : Top Brand Indeks

TOP : Posisi Ranking

Tabel 1 ini menunjukkan bahwa maskapai Garuda Indonesia menjadi maskapai unggulan dengan beradanya pada Top Brand Award kategori Airlines. Pada hal ini maskapai Garuda Indonesia menjadi nomer satu pada tahun 20132017, yang artinya konsumen domestik lebih mengapresiasi merek Garuda Indonesia dibanding para pesaingnya dan juga dapat meningkatkan persepsi kualitas merek dibenak konsumen. Menurut Kotler and Keller (2009:263), ekuitas merek adalah nilai tambah yang diberikan pada produk dan jasa. Ekuitas merek dapat tercermin dalam cara konsumen berpikir, merasa, dan bertindak dalam hubungannya dengan merek, dan juga harga, pangsa pasar, dan profitabilitas yang diberikan merek bagi perusahaan ekuitas merek dapat memberikan kekuatan dari suatu merek yang memberikan nilai terhadap perusahaan maupun konsumen. 
Dalam sudut pandang perusahaan, ekuitas merek memberikan keuntungan, aliran kas, dan pangsa pasar yang lebih tinggi sedangkan dalam sudut pandang konsumen, ekuitas merk berkaitan dengan keyakinan yang positif dan jelas tentang merek dalam benak konsumen. Ekuitas merek adalah salah satu faktor yang dapat mempengaruhi niat beli konsumen. Salah satu alasan pentingnya ekuitas merek adalah menciptakan nilai bagi konsumen dan perusahaan (Naeini et $a l ., 2015)$

Garuda Indonesia yang menjadi leader maskapai penerbangan di Indonesia pada tahun 2017 berdasarkan Top Brand Award, akanmemudahkan Garuda Indonesia menanamkan merek dibenak konsumen dan nantinya akan timbul kecendrungan konsumen lebih memilih merek tersebut dibanding merek pesaing. Menurut Margaretha (2008) menyebutkan bahwa preferensi merek yang kuat mempunyai derajat kesukaan konsumen yang kuat terhadap suatu merek. Perusahaan yang mampu mengembangkan preferensi merek akan mampu mempertahankan serangan dari para pesaing. Preferensi merek terbaik dapat memberikan jaminan kualitas bagi konsumennya.Christian dan Sunday (2013) mendefinisikan preferensi merek sebagai ukuran dari loyalitas konsumen dalam memilih suatu brand dibandingkan brand kompetitor lainnya, tetapi tetap menerima substitusi apabila brand yang dipilih tersebut tidak dapat ditemukan. Ketika perusahaan dapat menanamkan preferensi merek di benak konsumen maka akan lebih mudah untuk perusahaan dalam melakukan pemasaran produknya dikarenakan preferensi merek membuat derajat pemilihan produk atau jasa lebih condong ke perusahaan tersebut dibandingkan dengan produk atau jasa dari 
I Made Putra Adnyana, Peran Preferensi MerekMemediasi...

perusahaan pesaing. Setiap keputusan pembelian yang dilakukan oleh konsumen dalam membeli suatu produk selalu dipengaruhi oleh berbagai macam faktor. Salah satu faktor yang mempengaruhi keputusan pembelian tersebut adalah preferensi merek (Margaretha, 2008). Kebebasan konsumen dalam memilih suatu brand tidak dapat secara langsung menciptakan penjualan, melainkan menciptakan brand preference pada konsumen (Alamro dan Rowley, 2011).

Pertengahan tahun 2018 konsumen Garuda Indonesia dihebohkan dengan berita telah terjadinya masalah di internal Garuda Indonesia terkait rencana mogok pilot dan sejumlah karyawan hal ini didasarkan kekecewaan pilot dan karyawan atas berbagai kebijakan manajemen yang tidak sesuai dengan industri penerbangan, dimana regulasi dikeluarkan oleh dewan direksi yang umumnya berasal dari kalangan perbankan. Hal ini membuat keresahan pada konsumen Garuda Indonesia yang sudah melakukan pembelian tiket pada penerbangan sebelumnya dan juga konsumen berhak mendapatkan kenyamanan, keamanan dan keselamatan saat menggunakan jasa penerbangan. Rencana mogok tersebut bisa dibenarkan jika tidak berimbas pada aspek pelayanan pada konsumen. " Jika rencana mogok kerja terlaksana, berarti pilot akan berhadapan dengan konsumen. Yayasan Lembaga Konsumen Indonesia (YKLI) tidak mendukung pilot untuk melakukan mogok," kata Ketua Pengurus Harian YKLI Tulus Abadi dalam keterangannya di Jakarta, Sabtu (2/6/2018) dikutip dari (www.liputan6.com).

Kejadian mogoknya pilot dan sejumlah karyawan Garuda Indonesia serta pengaruh dari banyaknya maskapai baru yang amat percaya diri dan cukup sukses mengambil positioning sebagai low cost carrier yaitu persaingan melalui perang 
harga tiket murah menyebabkan keyakinan masyarakan terhadap kualitas pelayanan Garuda Indonesia menurun, hal tersebut berpengaruh pada keinginan masyarakan untuk menggunakan Garuda Indonesia sebagai moda transportasi udara. Menurut Simamora (2011:106), menyatakan bahwa niat beli terhadap suatu produk muncul karena adanya dasar kepercayaan terhadap suatu produk yang diiringi dengan kemampuan untuk membeli produk. Niat beli sangat berhubungan dengan kemungkinan konsumen melakukan pembelian yang di dorong oleh motivasi-motivasi tertentu. Chung et al. (2012), menyatakan bahwa niat pembelian dapat digunakan untuk mengukur tingkat transformasi pelanggan ke dalam perilaku pembelian terhadap produk tertentu, dan dapat digunakan sebagai indeks untuk memprediksi pengambilan keputusan pembelian konsumen. Semakin tinggi minat beli maka semakin tinggi kesempatan pembelian.

Kekhawatiran masyarakat akibat rencana mogok pilot Garuda Indonesia membuat niat menggunakan jasa Garuda Indonesia menjadi turun karena niat beli merupakan tahap konsumen melakukan keputusan pembelian. Menurut Randi (2016), menyatakan bahwa niat beli merupakan salah satu tahap penting lainnya yang harus diperhatikan oleh para pemasar dikarenakan niat merupakan suatu kondisi yang mendahului individu mempertimbangkan atau membuat keputusan untuk memilih sebuah produk atau layanan jasa. Kecenderungan konsumen untuk membeli suatu produk baik itu sekarang atau nanti disebut sebagai niat pembelian (Lakshmi dan Kavida, 2016).Menurut Schiffman dan Kanuk dalam Maghfiroh dkk. (2016), menyatakan bahwa niat beli adalah suatu bentuk pikiran yang nyata dari beberapa merek yang tersedia dalam periode waktu tertentu. Niat beli 
I Made Putra Adnyana, Peran Preferensi MerekMemediasi...

konsumen untuk melakukan pembelian dapat muncul akibat dari adanya rangsangan (stimulus) yang ditawarkan oleh perusahaan. Masing-masing stimulus tersebut dirancang untuk mempengaruhi tindakan pembelian oleh konsumen.

Berdasarkan fenomena tersebut maka peneliti tertarik meneliti seberapa besar pengaruh kekuatan merek dari Garuda Indonesia dapat membuat calon konsumennya memilih Garuda Indonesia dibandingkan yang lain karena adanya masalah rencana mogok pilot dan sejumlah karyawan yang nantinya akan berdampak pada niat menggunakan Garuda Indonesia. Maka dari itu peneliti tertarik membahas mengenai "Peran preferensi merek dalam memediasi hubungan antara ekuitas merekdengan niat beli”. Penelitian ini diharapkan dapat memberikan gambaran kepada pihak-pihak yang berkepentingan mengenai preferensi merek mempengaruhi ekuitas merek dan niat beli konsumen.

Berdasarkan latar belakang, maka rumusan masalah penelitian adalah sebagai berikut :1)Bagaimana pengaruh ekuitas merek terhadap niat beli tiket pesawat Garuda Indonesia? 2) Bagaimana pengaruh ekuitas merek terhadap preferensi merek maskapai Garuda Indonesia? 3) Bagaimana pengaruh preferensi merek terhadap niat beli tiket pesawat Garuda Indonesia? 4) Bagaimana peran preferensi merek dalam memediasi pengaruh ekuitas merek terhadap niat beli tiket pesawat Garuda Indonesia?

Berdasarkan rumusan masalah, maka tujuan dari penelitian ini adalah : 1) Untuk menjelaskan pengaruh ekuitas merek terhadap niat beli tiket pesawat Garuda Indonesia. 2) Untuk menjelaskan pengaruh ekuitas merek terhadap preferensi merek maskapai Garuda Indonesia. 3) Untuk menjelaskan pengaruh 
preferensi merek terhadap niat beli tiket pesawat maskapai Garuda Indonesia. 4) Untuk menjelaskan peran preferensi merek dalam memediasi pengaruh ekuitas merek terhadap niat beli tiket pesawat maskapai Garuda Indonesia. Berdasarkan tujuan penelitian yang telah diuraikan, adapun kegunaan dari penelitian ini adalah : 1) Kegunaan teoritis, untuk memperkuat hubungan variabel preferensi merek, ekuitas merek dan niat beli konsumen serta diharapkan hasil dari penelitian ini dapat menjadi bahan rujukan bagi peneliti-peneliti lainnya, yang melakukan penelitian dengan objek yang sama.2) Kegunaan praktis, untuk memberikan pertimbangan sebagai dasar pemikiran bagiGaruda Indonesia tentang informasi persepsi konsumen terhadap preferensi merek, ekuitas merek dan niat beli tiket pesawat maskapai Garuda Indonesia dan sebagai dasar perumusan strategi pemasaran dan memperkuat preferensi merek dan meningkatkan niat beli.

Konsumen memiliki keragaman yang menarik untuk dipelajari karena konsumen meliputi seluruh individu dari berbagai usia, latar belakang budaya, pendidikan, dan keadaan sosial ekonomi lainnya. Oleh karena itu, sangatlah penting untuk mempelajari bagaimana konsumen berperilaku dan faktor-faktor apa saja yang mempengaruhi perilaku tersebut. Perilaku konsumen pada hakikatnya untuk memahami mengapa konsumen melakukan dan apa yang mereka lakukan. Schiffman dan Kanuk (2008:6), mengemukakan bahwa studi perilaku konsumen adalah suatu studi mengenai bagaimana seorang individu membuat keputusan untuk mengalokasikan sumber daya yang tersedia (waktu, uang, usaha, dan energi). 
I Made Putra Adnyana, Peran Preferensi MerekMemediasi...

Niat beli merupakan tahap sebelum konsumen melakukan keputusan pembelian. Simamora (2011:106), menyatakan bahwa minat beli terhadap suatu produk muncul karena adanya dasar kepercayaan terhadap suatu produk yang diiringi dengan kemampuan untuk membeli produk. Febryan (2010: 244)menyatakan bahwa niat beli dapat terwujud ketika menemukan kriteria yang sesuai dengan keinginan pelanggan. Niat beli sering tidak muncul dalam pikiran yang terkadang menjadi alasan pelanggan untuk tidak membeli barang atau jasa yang sudah sering dibeli. Niat beliadalah kecenderungan konsumen untuk membeli suatu merek atau mengambil suatu tindakan yang berhubungan dengan pembelian yang diukur dengan tingkat kemungkinan konsumen melakukan suatu pembelian (Assael, 1998) dalam (Semuel dan Wijaya, 2008).

Seseorang atau individu akan mengalami proses pemikiran terlebih dahulu yang membentuk suatu persepsi sebelum akhirnya akan timbul niat untuk membeli. Menurut Mehta dalam Hidayati (2013) mengatakan bahwa niat beli didefinisikan sebagai kecenderungan konsumen untuk membeli suatu merek atau mengambil tindakan yang berhubungan dengan pembelian yang diukur dengan tingkat kemungkinan konsumen melakukan suatu pembelian.

Niat beli menciptakan suatu motivasi yang terus terekam dalam benak konsumen dan menjadi suatu keinginan yang sangat kuat yang pada akhirnya ketika seorang konsumen harus memenuhi kebutuhannya akan mengaktualisasikan apa yang ada didalam benaknya itu.

Menurut Kotler and Keller (2009:263), ekuitas merek adalah nilai tambah yang diberikan pada produk dan jasa. Ekuitas merek dapat tercermin dalam cara 
konsumen berpikir, merasa, dan bertindak dalam hubungannya dengan merek, dan juga harga, pangsa pasar, dan profitabilitas yang diberikan merek bagi perusahaanEkuitas merek dapat memberikan kekuatan dari suatu merek yang memberikan nilai terhadap perusahaan maupun konsumen.

Ekuitas merek menurut Kotler dan Amstrong (2008 : 282) adalah pengaruh diferensial positif bahwa jika pelanggan mengenal nama merek,pelanggan akan merespon produk dan jasa. Kotler memberikan pengertian "Brand equity is the value of a brand,based on the extent towhich it has high brand loyalty,name awareness,perceived quality, strong brandassocaiations, and other assets such as patens,trademarks,and channel relationships." Pengertian ini menyatakan bahwa ekuitas merek merupakan nilai dari merek,yang jumlahnya didasarkan atas tingkat loyalitas merek,kesadaran nama,kesan kualitas,kekuatan asosiasi merek,dan asetaset lainnya seperti paten, cap, dan saluran distribusi

Widjaja dkk. (2007) menyatakan ekuitas merek adalah seperangkat aset dan liabilitas merek yang berkaitan dengan suatu merek, nama dan simbolnya yang menambah atau mengurangi nilai yang diberikan oleh suatu barang dan jasa kepada perusahaan atau pelanggan. (Clow dan Baack, 2010: 278). Ekuitas merek mengacu pada utilitas tambahan atau nilai yang ditambahkan ke produk dari nama mereknya (Chen dan Chang, 2008). Ekuitas merek adalah salah satu faktor yang dapat mempengaruhi niat beli konsumen.

Preferensi merek merupakan salah satu bentuk apresiasi konsumen terhadap merek (Kotler dan Keller, 2009: 50), sedangkan menurut Lou dan Lee (2009: 49) bahwa preferensi merek adalah keadaan dimana konsumen menyukai merek 
I Made Putra Adnyana, Peran Preferensi MerekMemediasi...

karena merek tersebut menyenangkan. Preferensi merek terjadi pada tahap evaluasi alternatif dalam pengambilan keputusan pembelian. Preferensi merek ini menjadi penting, karena hal ini merupakan tahapan yang dilalui menuju loyalitas konsumen (Kotler dan Keller, 2009:82).

Preferensi merek dapat berarti kesukaan, pilihan terhadap suatu merek yang lebih disukai konsumen. Preferensi ini terbentuk dari persepsi terhadap merek produk atau jasa. Preferensi merek berkaitan erat dengan penilaian konsumen akan kepuasan atau ketidakpuasan terhadap suatu merek produk atau jasa, bahkan juga pada perusahaan tertentu (Tjiptono, 2007:58). Oleh karena itu teori preferensi ini dapat juga digunakan untuk menganalisis tingkat kepuasan bagi konsumen. Misalnya ada seorang konsumen ingin mengkonsumsi produk dengan sumber daya terbatas, maka ia harus memilih alternatif dari merek-merek yang ada, sehingga nilai guna atau utilitas yang diperoleh mencapai optimal. Studi seperti ini akan memberikan petunjuk untuk mengembangkan merek-merek baru, karakteristik atau ciri-ciri produk, harga, dan bauran pemasaran lainnya (Kotler dan Keller, 2009:53).

Penelitian yang dilakukan oleh Sasnelwati dan Indriyenni (2017) menyatakan bahwa terdapat pengaruh signifikan antara variabel ekuitas merek dengan niat beli pada produk Skin Foam Garnier. Irzandy dkk. (2017) menyatakan bahwa variabel Ekuitas Merek memiliki pengaruh yangsignifikan terhadap Niat beli. Dalam pembahasan menunjukkan bahwa banyak sekali konsumen cenderung melihat merek simPATI merupakan merek yang terkenal dan dari hasil tersebut terbukti mempengaruhi niat beli konsumen. 
Lakshmi dan Kavida (2016), pada penelitannya tentang niat beli peralatan rumah tangga di Chennai, menyatakan bahwa niat beli dipengaruhi secara signifikan oleh empat dari lima dimensi ekuitas merek yakni kesadaran merek, asosiasi merek, kualitas yang dirasakan, loyalitas merek dan kepercayaan merek. Ini adalah penunjuk yang signifikan bagi pemasar barang tahan lama dan peralatan rumah tangga.

$\mathrm{H}_{1}$ : Ekuitas merek berpengaruh secara positif dan signifikan terhadap niat beli

Isabel Buil and Eva Martinez (2013) pada penelitiannya menyimpulkan indikator keseluruhan ekuitas merek memiliki pengaruh positif terhadap preferensi merek pada konsumen.Penelitian (Moradi dan Zarei (2011) menunjukan ekuitas merek berbasis konsumen memiliki pengaruh langsung dan positif terhadap preferensi merek konsumen. Penelitian yang dilakukan Mahrinasari (2014) menyatakan bahwa ekuitas merek dianggap sebagai brand attitude dan brand image, dan konsekuensi dari ekuitas merek dianggap sebagai preferensi merek dan niat beli. Sehingga ekuitas merek memberikan efek positif terhadap preferensi merek.

$\mathrm{H}_{2}$ : Ekuitas merek berpengaruh secara positif dan signifikan terhadap preferensi merek.

Penelitian Emor dan Pangemanan (2015) menunjukan Preferensi merek itu sendiri memiliki pengaruh positif yang signifikan terhadap niat beli.Chimboza and Muntandwa (2007) melakukan penelitian untuk menilai tingkat kesadaran merek dan faktor yang mendasari preferensi merek pada susu di Chitungwiza dan pasar perkotaan Hararedi Zimbabwe. Penelitian yang telah dilakukan oleh Utami dan Sumaryono (2008) dengan tujuan untuk mengetahui apakah terdapat pengaruh 
dari gaya hidup, konsep diri, kepribadian, serta respon iklan terhadap preferensi merek ponsel Nokia. Hasil pada penelitian ini menyatakan bahwa masing-masing variabel terikat gaya hidup, konsep diri, kepribadian serta respon atas iklan memiliki pengaruh yang signifikan terhadap preferensi merek ponsel Nokia.

$\mathrm{H}_{3}$ : Preferensi merek berpengaruh secara positif dan signifikan terhadap niat beli.

Hasil penelitian Sanjaya (2012) menunjukan bahwa Brand Preference yang Memediasi Hubungan Antara Brand Equity terhadap Purchase Intention pada PT. SunLife Financial di Surabaya memiliki pengaruh signifikansi postif.Prabhawedasattya (2013) menunjukanbahwa semakin baik ekuitas merek dari produk Apple iPhone, maka semakin tinggi pula preferensi konsumen dalam memilih merek Apple iPhone. Chen (2008) mengungkapkan dalam penelitiannya terhadap kedua efek ekuitas merek dengan preferensi merek dan preferensi merek pada niat memiliki signifikan yang positif.

$\mathrm{H}_{4}$ : Preferensi merek memediasi pengaruh ekuitas merek terhadap niat beli

Berdasarkan hipotesis yang telah diuraikan sebelumnya, maka dapat digambarkan kerangka konseptual sebagai berikut:

\section{Gambar 1. Kerangka Konseptual}

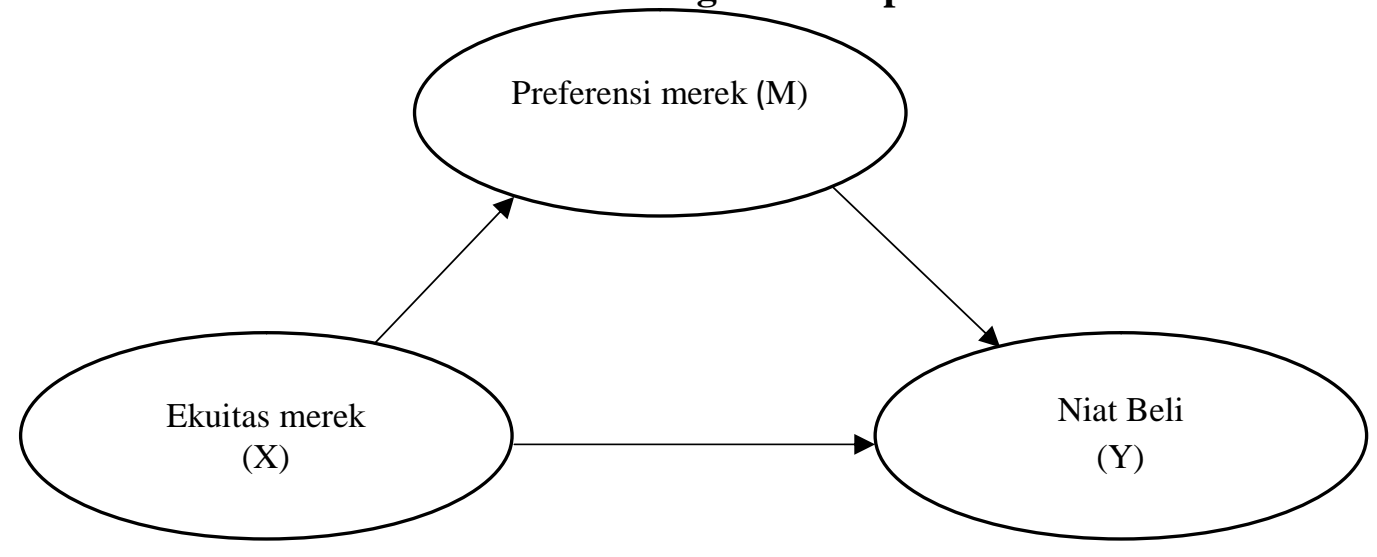




\section{METODE PENELITIAN}

Penelitian ini menggunakan pendekatan kuantitatif yang berbentuk asosiatif, karena bertujuan untuk mengetahui hubungan dua variabel atau lebih (Sugiyono, 2013:55) yaitu variabel bebas ekuitas merek(X) dengan satu variabel terikat yaitu niat beli(Y) dengan variabel mediasi yaitu preferensi merek(M).Wilayah Kota Denpasar. Lokasi ini dipilih karena Kota Denpasar memiliki jumlah penduduk tertinggi di Bali yang mencapai angka 930.600 jiwa pada bulan Maret Tahun 2018. Sehingga memungkinkan peneliti menemukan konsumen potensial (www.denpasarkota.bps.go.id).

Variabel Endogen pada penelitian ini adalah niat beli (Y). Variabel Intervening pada penelitian ini adalah preferensi merek (Y) dan Variabel Eksogen dalam penelitian ini adalah ekuitas merek (X). Populasi dalam penelitian ini adalah masyarakat Kota Denpasar yang telah mengenyam pendidikan SMA dan pernah menggunakan jasa penerbangan yang ada di Indonesia. Sampel adalah bagian dari populasi yang di harapkan dapat mewakili keseluruhan populasi tersebut. Populasi dalam penelitian adalah masyarakat Kota Denpasar yang telah mengenyam pendidikan SMA dan pernah menggunakan jasa penerbangan yang ada di Indonesia tetapi belum pernah menggunakan maskapai Garuda Indonesia. Teknik penentuan sampel yang digunakan pada penelitian ini adalah probability sampling dengan metode simple random sampling yang memungkinkan setiap unit sampling sebagai unsur populasi memperoleh peluang yang sama untuk menjadi sampel.Menurut Sugiyono (2014:112) untuk memperoleh hasil yang baik ukuran sampel responden yang diambil untuk mengisi kuesioner dapat ditentukan 
paling sedikit 5 - 10 kali jumlah indikator yang diteliti. Jumlah indikator yang diteliti dalam penelitian ini adalah sebanyak 11 indikator sehingga banyak responden yang diambil sebagai sampel adalah sebanyak 11 X $10=110$ responden. Jadi responden yang diambil sebanyak 110 orang responden berdasarkan kuisioner yang akan disebarkan, data kualitatif. Teknik analisis data yang digunakan adalah Structural Equation Modelling (SEM) dengan Amos Versi 22 dan SPSS Versi 21.

\section{Gambar 2. Diagram Penelitian}

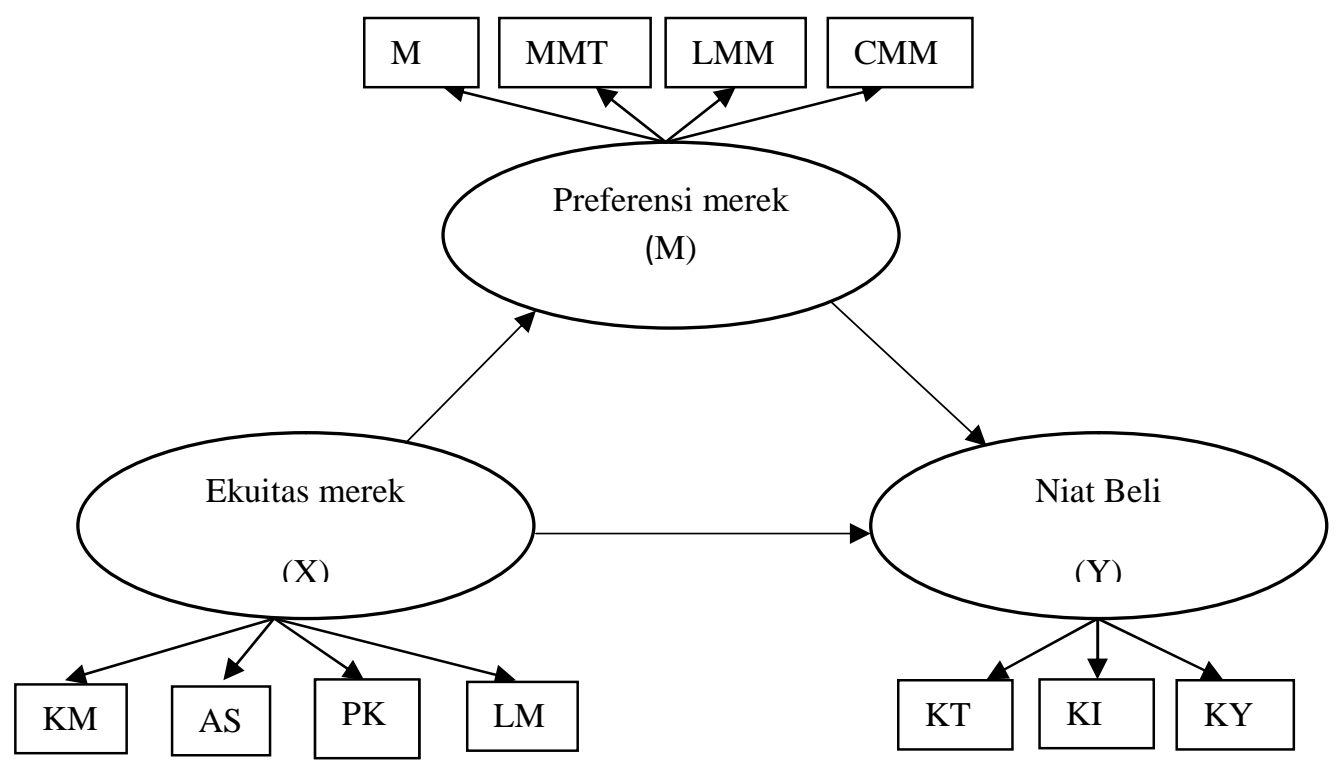

\section{HASIL DANPEMBAHASAN}

Responden penelitian digambarkan secara umum dengan menyajikan karakteristiknya dilihat dari beberapa variabel demografi yaitu jenis kelamin, usia, pekerjaan, pendidikan.

Karakteristik responden berdasarkan jenis kelamin dapat dilihat pada Tabel3berikut: 
Tabel 3.

Karakteristik Responden Berdasarkan Jenis Kelamin

\begin{tabular}{cccc}
\hline No & Jenis Kelamin & $\begin{array}{c}\text { Jumlah Berdasarkan Jenis } \\
\text { Kelamin }\end{array}$ & Persentase \\
\hline 1 & Laki-Laki & 61 & $55,5 \%$ \\
2 & Perempuan & 49 & $44,5 \%$ \\
& Total & $\mathbf{1 1 0}$ & $\mathbf{1 0 0 \%}$ \\
\hline
\end{tabular}

Sumber: Data diolah, 2018

Berdasarkan Tabel 3 di atas terlihat bahwa karakteristik responden berdasarkan jenis kelamin dengan jenis kelamin laki-laki sebanyak 61 orang dan dengan jenis kelamin perempuan sebanyak 49 orang. Berdasarkan hal tersebut dapat disimpulkan bahwa mayoritas responden dalam penelitian lebih banyak jenis kelamin laki-laki dari pada jenis kelamin perempuan.

Karakteristik responden berdasarkan umur dapat dilihat pada Tabel 4 berikut:

Tabel 4.

Karakteristik Responden Berdasarkan Umur

\begin{tabular}{cccc}
\hline No & Umur & Jumlah Berdasarkan Umur & Persentase \\
\hline 1 & 19-21 Tahun & 40 Orang & 36,4 \\
2 & 22-26 Tahun & 56 Orang & 50,9 \\
3 & 27-31 Tahun & 5 Orang & 4,5 \\
4 & 32-36 Tahun & 1 Orang & 0,9 \\
5 & 37-42 Tahun & 1 Orang & 0,9 \\
6 & Diatas 42 Tahun & 7 Orang & 6,3 \\
& Total & $\mathbf{1 1 0}$ Orang & $\mathbf{1 0 0 , 0 0}$ \\
\hline
\end{tabular}

Sumber: Data diolah, 2018

Berdasarkan Tabel 4 di atas terlihat bahwa karakteristik responden berdasarkan umur19-21 tahun sebanyak 40 orang, umur 22-26 tahun sebanyak 56 orang, 27-31 tahun sebanyak 5 orang, umur 32-36 tahun sebanyak 1 orang, umur 37-42 tahun sebanyak 1 orang dan umur Diatas 42 tahun sebanyak 7 orang. Berdasarkan hal tersebut dapat disimpulkan bahwa mayoritas responden dalam penelitian ini berusia di antara 22-26 tahun. 
Tabel 5.

Karakteristik Responden Berdasarkan Status Pekerjaan

\begin{tabular}{clcc}
\hline No & Status Pekerjaan & $\begin{array}{c}\text { Jumlah Berdasarkan Status } \\
\text { Pekerjaan }\end{array}$ & Persentase \\
\hline 1 & Mahasiswa & 76 Orang & 69,1 \\
2 & Karyawan Swasta & 18 Orang & 16,4 \\
3 & PNS & 2 Orang & 1,8 \\
4 & Pengusaha & 11 Orang & 10 \\
5 & Lainnya & 3 Orang & 2,7 \\
& Total & $\mathbf{1 1 0}$ Orang & $\mathbf{1 0 0 , 0 0}$ \\
\hline
\end{tabular}

Sumber: Data diolah, 2018

Berdasarkan Tabel 5 di atas terlihat bahwa karakteristik responden berdasarkan pekerjaan atau status sosial dalam penelitian yaitu mahasiswa sebanyak 76 orang, karyawan swasta sebanyak 18 orang, PNS sebanyak 2 orang, pengusaha sebanyak 11 orang dan lain-lain sebanyak 3 orang. Berdasarkan hal tersebut dapat disimpulkan bahwa mayoritas responden dalam penelitian ini

Tabel 6.

Karakteristik Responden Berdasarkan Pendidikan Terakhir

\begin{tabular}{clcc}
\hline No & \multicolumn{1}{c}{$\begin{array}{c}\text { Pendidikan } \\
\text { Terakhir }\end{array}$} & $\begin{array}{c}\text { Jumlah Berdasarkan Pendidikan } \\
\text { Terakhir }\end{array}$ & Persentase \\
\hline 1 & SMA/Sederajat & 39 Orang & 35,5 \\
2 & Diploma & 16 Orang & 14,5 \\
3 & S1 & 54 Orang & 49,1 \\
4 & S2 & 1 Orang & 0,9 \\
5 & S3 & 0 & 0 \\
& Total & $\mathbf{1 1 0}$ Orang & $\mathbf{1 0 0 , 0 0}$ \\
\hline
\end{tabular}

Sumber: Data diolah, 2018

Berdasarkan Tabel 6 di atas terlihat bahwa karakteristik responden berdasarkan pendidikan terakhir yaitu masih duduk di bangku SMA/sederajat sebanyak 39 orang, Diploma sebanyak 16 orang, S1 sebanyak 54 orang dan S2 sebanyak 1 orang. Berdasarkan hal tersebut dapat disimpulkan bahwa mayoritas responden dalam penelitian ini berpendidikan terakhir S1.

Suatu kuesioner dikatakan valid jika pernyataan pada kuesioner mampu untuk mengungkapkan sesuatu yang diukur oleh kuesioner tersebut. Hasil uji validitas instrumen penelitian akan disajikan pada Tabel 7. 
Tabel 7.

Hasil Uji Validitas

\begin{tabular}{cccc}
\hline Variabel & Instrumen & Pearson Correlation & Keterangan \\
\hline Ekuitas Merek & X1.1 & 0,924 & Valid \\
(X1) & X1.2 & 0,891 & Valid \\
& X1.3 & 0,902 & Valid \\
X1.4 & M1.1 & 0,850 & Valid \\
Preferensi Merek & M1.2 & 0,878 & Valid \\
(Y1) & M1.3 & 0,903 & Valid \\
& M1.4 & 0,940 & Valid \\
Niat Beli & Y1.1 & 0,933 & Valid \\
(Y2) & Y1.2 & 0,906 & Valid \\
& Y1.3 & 0,905 & Valid \\
\end{tabular}

Sumber: Data diolah, 2018

Tabel 7menunjukkan variabel Ekuitas Merek memiliki pearson correlation dari $0,850-0,924(>0,30)$, hal ini berarti bahwa pernyataan tersebut valid. Variabel Preferensi Merek memiliki pearson correlation dari 0,878 - 0,940 (> 0,30), hal ini berarti bahwa pernyataan dalam kuesioner adalah valid. Variabel Niat Beli memiliki pearson correlation 0,862 - 0,906 (>0,30), hal ini berarti bahwa pernyataan tersebut juga valid

Pengujian reliabilitas dalam penelitian ini menggunakan metode Cronbach's Alpha. Instrumen dikatakan reliable untuk mengukur variabel bila berada di atas angka 0,60 . Hasil pengujian reliabilitas instrument dapat dilihat pada Tabel 8.

\section{Tabel 8.}

Hasil Uji Reliabilitas

\begin{tabular}{ccc}
\hline Variabel & Cronbach's Alpha & Keterangan \\
\hline Ekuitas Merek & 0,906 & Reliabel \\
Preferensi Merek & 0,933 & Reliabel \\
Niat Beli & 0,868 & Reliabel \\
\hline
\end{tabular}

Sumber :Data diolah, 2018

Berdasarkan Tabel 8 dapat dilihat bahwa nilai alpha dihitung masingmasing variabel lebih besar dari Cronbach's Alpha tabel yaitu 0,60 sehingga dapat disimpulkan bahwa pernyataan dalam kuesioner tersebut reliabel. 
I Made Putra Adnyana, Peran Preferensi MerekMemediasi...

Uji normalitas data menggunakan metode univariate normality dengan melihat xxc `koefisien index skew univariate (kecondongan) dan index kurtosis univariate (tinggi-datar). Data memenuhi syarat normalitas data jika koefisien index skew univariate dan index kurtosis univariate berada di antara $\pm 2,58(-2,58$ $\leq \mathrm{CR} \leq+2,58)$. Jika di luar angka ini, dapat dikatakan bahwa data dalam kondisi tidak normal. Hasil uji normalitas ditunjukan dalam Tabel 9.

Tabel 9.

Normalitas Data Penelitian

\begin{tabular}{lrrrrrr}
\hline Variable & min & max & skew & c.r. & kurtosis & c.r. \\
\hline $\mathrm{m} 1.1$ & 2.000 & 5.000 & -.411 & -1.760 & -.112 & -.241 \\
$\mathrm{x} 1.4$ & 2.000 & 5.000 & -.365 & -1.564 & -.617 & -1.321 \\
$\mathrm{~m} 1.4$ & 2.000 & 5.000 & -.234 & -1.000 & -.733 & -1.570 \\
$\mathrm{~m} 1.3$ & 1.000 & 5.000 & -.624 & -2.672 & .172 & .368 \\
$\mathrm{~m} 1.2$ & 2.000 & 5.000 & -.374 & -1.602 & -.843 & -1.804 \\
$\mathrm{y} 1.3$ & 2.000 & 5.000 & -.449 & -1.921 & -.015 & -.033 \\
$\mathrm{y} 1.2$ & 2.000 & 5.000 & -.817 & -3.498 & .817 & 1.749 \\
$\mathrm{y} 1.1$ & 3.000 & 5.000 & -.113 & -.484 & -.620 & -1.326 \\
x1.1 & 3.000 & 5.000 & -.290 & -1.240 & -.762 & -1.631 \\
x1.2 & 2.000 & 5.000 & -.746 & -3.194 & -.310 & -.665 \\
x1.3 & 2.000 & 5.000 & -.759 & -3.248 & -.246 & -.527 \\
Multivariate & & & & & 22.380 & 6.940 \\
\hline Sumber: Data diolah, 2018 & & & & & &
\end{tabular}

Hasil penelitian ini menunjukan bahwa nilai determinant of sample covariance matrix $=0.000120$ dan di atas angka nol.Dengan demikian, dapat disimpulkan bahwa tidak ada multicollinearity atau singularity dalam data yang digunakan. Oleh karena itu, data dalam penelitian ini dapat digunakan dalam analisis.

Dalam penelitian ini tidak adanya data yang outlier.Jadi, dapat dikatakan bahwa pada data yang ada, faktor pengganggunya tidak ditemukan sehingga data yang ada dapat digunakan. Dalam analisis penelitian, bila tidak ada alasan khusus 
untuk mengeluarkan kasus yang mengindikasikan adanya outlier, maka kasus itu harus tetap diikutsertakan dalam analisis selanjutnya (Ferdinand, 2012: 108).

\section{Gambar 3. Model Persamaaan Struktural}

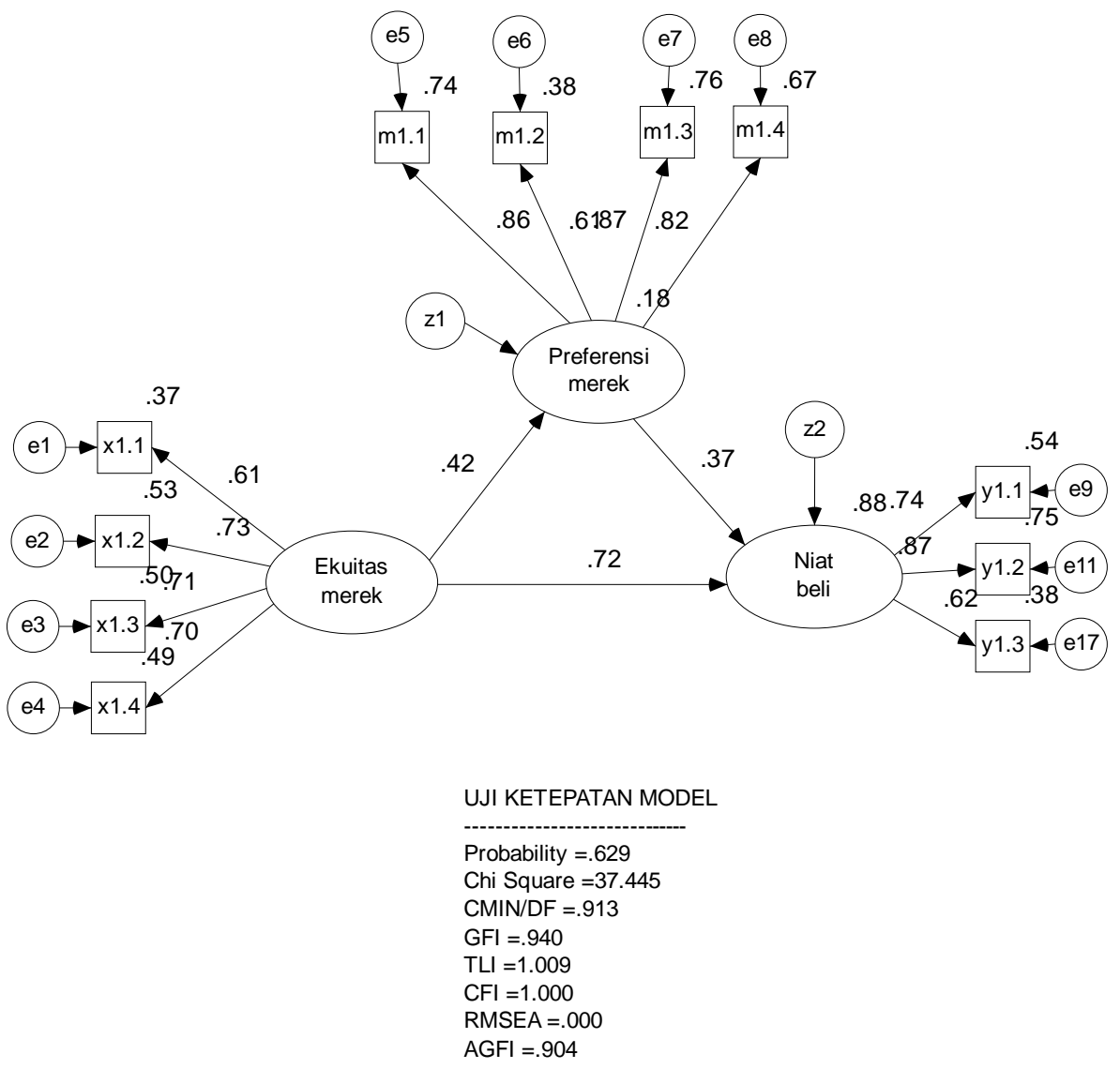

Hasil pengujian kesesuaian model pada Gambar 3 menunjukkan nilai chisquare sebesar 37,445 dan nilai-nilai probabilitas sebesar 0,629 yang berada di atas batas signifikansinya yaitu 0,05 . selain itu, nilai indeks pengukuran kesesuaian model yang meliputi GFI $(0,940)$, AGFI $(0,904)$, TLI $(1,009)$, CFI (1,000), RMSEA $(0,000)$, dan CMIN/DF $(0,913)$ berada dalam rentang nilai yang diharapkan. Semua ini menunjukkan bahwa tidak terdapat perbedaan antara matriks kovarians sampel dan matriks kovarians populasi yang diestimasi sehingga full model SEM ini dapat diterima. 
Tabel 10.

Hasil Uji Hipotesis Berdasarkan Regression Weights dan Standardized Regression Weights Pada Model Struktural

\begin{tabular}{lrlrc}
\hline & & & Estimate & p-Value \\
\hline Pref_merek & $<---$ & Ekuitas_merek & .423 & 0,000 \\
Niat_beli & $<--$ & Pref_merek & .370 & 0,000 \\
Niat_beli & $<---$ & Ekuitas_merek & .718 & 0,000 \\
\hline Sumber: Data & diolah, 2018 & &
\end{tabular}

Berdasarkan hasil uji hipotesismodelpersamaan struktural pada Tabel 10 maka diperoleh penilaian sebagai berikut pengaruh ekuitas merek terhadap niat beli memiliki nilai $\mathrm{p}$ sebesar 0,000 berada dibawah cut-off value yaitu 0,05 sehingga Hoditolak yang berarti ekuitas merek berpengaruh secara positif dan signifikan terhadap niat beli. Angka korelasi yang ditunjukkan pada kolom estimate sebesar 0,718 menunjukkan seberapa erat hubungan kedua konstruk tersebut. Hasil tersebut memperlihatkan bahwa nilai tambah yang dihasilkan pada merek Garuda Indonesia dapat membuat calon konsumen memiliki niat yang tinggi untuk membeli tiket pesawat Garuda Indonesia. Hasil penelitian ini didukung oleh hasil penelitian sebelumnya yang dilakukan oleh Sasnelwati dan Indriyenni (2017), menyatakan ekuitas merek berpengaruh positif dan signifikan terhadap niat beli

Pengaruh ekuitas merek terhadap preferensi merek memiliki nilai p sebesar 0,000 berada dibawah cut-off value yaitu 0,05 sehingga Hoditolak yang berarti ekuitas merek berpengaruh secara positif dan signifikan terhadap preferensi merek. Angka korelasi yang ditunjukkan pada kolom estimate sebesar 0,423 menunjukkan seberapa erat hubungan kedua konstruk tersebut. Hasil tersebut memperlihatkan bahwa semakin baik nilai tambah yang dirasakan oleh calon konsumen Garuda Indonesia maka akan semakin baik pula preferensi merek 
dimata calon konsumen. Hasil penelitian ini didukung oleh hasil penelitian sebelumnya yang dilakukan oleh Isabel Buil dan Eva Martinez (2013) pada penelitiannya menyimpulkan indikator keseluruhan ekuitas merek memiliki pengaruh positif terhadap preferensi merek pada konsumen.

Pengaruh preferensi merek terhadap niat beli memiliki $\mathrm{N}=$ nilai $\mathrm{p}$ sebesar 0,000 berada dibawah cut-off value yaitu 0,05 sehingga Hoditolak yang berarti preferensi merek berpengaruh secara positif dan signifikan terhadap niat beli. Angka korelasi yang ditunjukkan pada kolom estimate sebesar 0,370 menunjukkan seberapa erat hubungan kedua konstruk tersebut. Hasil tersebut memperlihatkan bahwa semakin baik preferensi merek di mata calon konsumen maka akan semakin banyaknya calon konsumen yang berniat membeli tiket pesawat Garuda Indonesia seiring berjalannya waktu.Hasil penelitian ini didukung oleh hasil penelitian sebelumnya yang dilakukan olehEmor dan Pangemanan (2015) menunjukan Preferensi merek itu sendiri memiliki pengaruh positif yang signifikan terhadap niat beli

Menghitung pengaruh tidak langsunguji mediasi variabel Preferensi merek (M) atas hubungan Ekuitas merek (X) terhadap niat beli (Y)uji Sobel dirumuskan dengan persamaan berikut:

$$
\begin{aligned}
& \text { a } \quad=0,423 \\
& \mathrm{~b} \quad=0,370 \\
& \mathrm{~S}_{\mathrm{a}}=0,153 \\
& \mathrm{~S}_{\mathrm{b}} \quad=0,061 \\
& \mathrm{~S}_{\mathrm{ab}}=\sqrt{\mathrm{b}^{2} \mathrm{~S}_{\mathrm{a}}^{2}+\mathrm{a}^{2} \mathrm{Sb}^{2}+\mathrm{S}_{\mathrm{a}}^{2} \mathrm{Sb}^{2}} \\
& S_{\mathrm{ab}}=\sqrt{0,370^{2} 0,153^{2}+0,423^{2} 0,061^{2}+0,153^{2} 0,061^{2}} \\
& \mathrm{~S}_{\mathrm{ab}} \quad=\sqrt{0,00395}=0,0628 \\
& \mathrm{t} \quad=\frac{\mathrm{a}}{\mathrm{s}}=\frac{0,4 \quad x 0,3}{0,0}=\frac{0,1}{0,0}=2,4920 \\
& \text { t hitung }=2,4920
\end{aligned}
$$


t tabel (df: 97, a: 0,05) =1,9847

$\mathrm{t}$ hitung $>\mathrm{t}$ tabel $=2,4920>1,9847$

Keterangan :

$\mathrm{S}_{\mathrm{ab}} \quad=$ besarnya standard error tidak langsung

$\mathrm{S}_{\mathrm{a}} \quad=$ standard error koefisien a

$\mathrm{S}_{\mathrm{b}}=$ standard error koefisien $\mathrm{b}$

$\mathrm{a} \quad=$ koefisien jalur X1 terhadap M1

$\mathrm{b} \quad=$ koefisien jalur M1 terhadap Y1

$\mathrm{ab}=$ hasil kali koefisien jalur X1 terhadap koefisien jalur M1 (a) dengan jalur M1 terhadap Y1 (b).

Oleh karena $\mathrm{Z}$ hitung sebesar 2,4920 > 1,9847 artinya preferensi merek (M1) sebagai variabel mediasi pengaruh tidak langsung ekuitas merek (X1) terhadap niat beli (Y1). Variabel preferensi merek sebagai variabel mediasi berpengaruh signifikan secara tidak langsung terhadap niat beli melalui variabel ekuitas merek. Hasil tersebut menyatakan bahwaaspek-aspek pada preferensi merek memiliki peran penting pada nilai tambah merek Garuda Indonesia dan pada akhirnya konsumen berniat untuk membeli tiket pesawat Garuda Indonesia.Dengan demikian hasil ini sejalan dengan penelitian dari Prabhawedasattya (2013), dalam penelitiannya menunjukan bahwa preferensi merek memediasi hubungan antara ekuitas merek dengan niat beli secara tidak langsung.

\section{SIMPULAN DAN SARAN}

Berdasarkan hasil analisis yang telah diuraikan maka dapat ditarik simpulan untuk menjawab rumusan masalah adalah Ekuitas Merek berpengaruh positif dan signifikan terhadap preferensi merek Garuda Indonesia yang artinya semakin baik Ekuitas Merek maka preferensi merek Garuda Indonesia akan baik dimata calon konsumen.Ekuitas Merek berpengaruh positif dan signifikan terhadap niat beli 
tiket pesawat Garuda Indonesia yang artinya semakin baik ekuitas merek yang dirasakan maka calon konsumen akan semakin berniat membeli tiket pesawat Garuda Indonesia.Preferensi Merekberpengaruh positif dan signifikan terhadap niat beli tiket pesawat Garuda Indonesia yang artinya semakin baik preferensi merek di mata calon konsumen maka akan semakin banyaknya calon konsumen yang berniat membeli tiket pesawat Garuda Indonesia seiring berjalannya waktu.Preferensi merek sebagai variabel mediasi berpengaruh signifikan secara tidak langsung dalam memediasi ekuitas merek dengan niat beli tiket pesawat Garuda Indonesia yang artinya bahwa aspek-aspek pada preferensi merek memiliki peran penting pada nilai tambah merek Garuda Indonesia dan pada akhirnya konsumen berniat untuk membeli tiket pesawat Garuda Indonesia. Berdasarkan simpulan yang telah diuraikan, maka dapat diajukan saran bahwa Garuda Indonesiaperlu memperhatikan loyalitas merek dikarenakanloyalitas merek merupakan satu-satunya unsur equitas merek yang terkait dengan perolehan laba di masa depan.

Garuda Indonesia harus lebih meningkatkan preferensi merek perusahaan di benak calon konsumen guna terciptanya pandangan dimana ketika calon konsumen hendak melakukan perjalan udara ia akan lebih cenderung mengingat merek Garuda Indonesia pertama kali. Oleh karena itu, akan lebih baik apabila Garuda Indonesia senantiasa mengerahkan upaya yang mampu meningkatkan preferensi mereknya. Terlebih lagi dengan banyaknya jumlah pesaing yang ada pada industri penerbangan. 
I Made Putra Adnyana, Peran Preferensi MerekMemediasi...

Bagi peneliti berikutnya, untuk meningkatkan kualitas penelitian sebaiknya memperluas ruang lingkup penelitian dan menambahkan beberapa variabel seperti kualitas pelayanan, WOM, dan e-WOM.

\section{REFERENSI}

Alamro, Ahmed, Jennifer Rowley. (2011). Antecedents od Brand preference forMobile Telecommunication Services. Journal of Product and BrandManagement, 20 (6), pp. 475-486.

BPS Kota Denpasar, (2018). Penduduk KotaDenpasar.www.denpasarkota.bps.go.id. Diakses pada 5 Maret 2018.

Chen, C.F, dan Chang, Y.Y., 2008. Airline brand equity, brand preference, and purchase intentions-The moderating effects of switching costs. Jurnal Manajemen Transportasi Udara, 14(2) pp. 40-42.

Chung, C. H., Chen, H. T. \& Lin, C. Y. (2012). A Study of Brand Perception, Advertising Effectiveness and Relationship Quality on Purchase Intention, Journal of Data Analysis. Volume 7, No.5, pp. 137 - 158.

Christian, Amadi, Ezekiel Maurice Sunday. (2013). Factors Influencing Brandpreference of Beer Consumption in Port-Harcourt Metropolis, River State,Nigeria. European Journal of Business and Management, 5(17) pp. 76-87.

Clow, K.E., and Baack, D., (2010). Integrated Advertising, Promotions, and Marketing Communications. Global Edition. Pearson Prentice Hall., United States of America.

Emor Angelina M Dan Pangemanan S. S. (2015). Analyzing Brand Equity on Purchase Intention Through Brand Preference hof Samsung Smartphone user in Manado. Jurnal EMBA,3(2), Hal. 124-131

Febryan, F., (2010), The Power of Selling, Jakarta, PT. Elex Media Komputindo

Ferdinand, Augusty. (2014). Metode Penelitian Manajemen, Semarang, Badan Penerbit Universitas Diponegoro.

Garuda Indonesia. Garuda Indonesia Experience. www.garuda-indonesia.com. Diaksespada 19 April 2018 
Hidayati, Tri Asih; Suharyono; Fanani, Dahlan. (2013). Pengaruh Citra Merek Terhadap Minat Beli Dan Keputusan Pembelian Konsumen. Jurnal Administrasi Bisnis. 2(1), hal. 162-171

Iriani, Nur I. (2011). Pengaruh Dimensi Brand Equity (Ekuitas Merek) Terhadap Keputusan Pembelian Kartu Telepon Selular Telkomsel di Kota Malang.Jurnal Aplikasi Manajemen, 9(2), Hal. 481-490.

Irzandy M. A. H., Suharyono, dan Zainul Arifin. (2017). Pengaruh Ekuitas MerekTerhadap Minat Beli Dan Dampaknya Pada Keputusan Pembelian. Jurnal Administrasi Bisnis (JAB) ,51(1). Hal. 56-70.

Isabel Buil and Eva Martinez. (2013). The influence of brand equity on consumer responses. Journal of Consumer Marketing ,30(1),pp. 62-74.

Kotler, Philip and Gary Armstrong. (2008). Prinsip-Prinsip Pemasaran. Edisi 12. Jilid 1. Jakarta:Erlangga.

Kotler, Philip dan Kevin L. Keller. (2009). Marketing Management. Pearson International Edition : New Jersey

Lakshmi S. dan Kavida V. (2016), Impact of Brand Equity on Purchase Intention of Home Appliances. The IUP Journal of Brand Management, 13(4), pp. 96-111

Liputan 6, 2018. YLKI Ingatkan Rencana Mogok Pilot Garuda Langgar Hak Konsumen.https://www.liputan6.com/bisnis/read/3546913/ylki-ingatkanrencana-mogok-pilot-garuda-langgar-hak-konsumen. Diakses pada 5 Agustus 2018

Lou, G.T. \& Lee, S.H. (2009). "Consumers' trust in a Brand and The Linkto Brand Loyality." Journal of Marketing FocusedManagement, Vol. 4, 341370 .

Maghfiroh, As'alul; Arifin, Zainul; Sunarti. (2016). Pengaruh Citra Merek Terhadap Minat Beli Dan Keputusan Pembelian (Survei pada Mahasiswa Program Studi Administrasi Binis Tahun Angkatan 2013/2014 Fakultas Ilmu Administrasi Universitas Brawijaya Malang Pembeli Indosat). Jurnal Administrasi Bisnis. Volume 40, No. 1, h. $132-140$

Mahrinasari MS. (2014). Model Citra Tanggung Jawab Sosial Perusahaan dalam Membangun Ekuitas Merek. Disertasi, Program Pascasarjana Fakultas Ekonomika dan Bisnis, Universitas Gadjah Mada, Yogyakarta. 
I Made Putra Adnyana, Peran Preferensi MerekMemediasi...

Margaretha Ardhanari. (2008). Customer Satisfaction Pengaruhnya Terhadapbrand Preference Dan Repurchase Intention Private Brand. Jurnal Riset Ekonomi dan Bisnis , 8(2)Hal. 58-69

Moradi H., dan Zarei A. (2011). The Impact of Brand Equity on Purchase Intention and Brand Preference-the Moderating Effects of Country of Origin Image. Australian Journal of Basic and Applied Sciences, 5(3), pp. 539-545

Naeini A.L, Azali P. R, and Tamaddoni K.S. Impact of Brand Equity on Purchase Intention and Development, Brand Preference and Customer Willingness toPay Higher Prices. Journal Management and Administrative Sciences Review,4(3), pp. 616-626

Prabhawedasattya IGA.P.A. (2013). Pengaruh Ekuitas Merek Terhadap Preferensi Merek Dan Niat Beli Konsumen Pada Produk Iphone Di Kota Denpasar. Universitas Udayana.E-Jurnal Manajemen Unud, Vol. 2(11). Hal.15251551.

Randi dan Heryanto, Meyzi. (2016). Pengaruh Citra Merek Terhadap Minat Beli Pada Makanan Fast Food Ayam Goreng (Studi Pada Konsumen Texas Chicken Pekanbaru). Jurnal Online Mahasiswa Fakultas Ilmu Sosial dan Ilmu Politik. Volume 3, No. 2, h. 1-9

Sanjaya Edwin (2012). Pengaruh Brand Equity Terhadap Purchase Intention Melalui Brand PreferencePada Produk Pt. Sunlife Financial Di Surabaya. Jurnal Ilmiah Mahasiswa Manajemen. 1(2), hal. 89-101

Sasnelwati, Indriyenni. (2017). Analisis Pengaruh Iklan Menggunakan Selebritis Sebagai Icon Dan Brand Equity Terhadap Minat Beli Konsumen Skin Foam Garnier Pada Remaja Kota Padang. Majalah Ilmiah, 24(1), Hal. $162-176$

Schiffman, Leon G. dan Kanuk, leslie Lazar. Perilaku Konsumen. 9 ed. Amerika Serikat: Pearson Prentice Hall.

Sekaran, Uma .(2003). Research Methods For Business: A Skill BuildingAproach, New York-USA: John Wiley and Sons, Inc.

Simamora, Bilson. (2011). Memenangkan Pasardengan Pemasaran Efektifdan Profitabel. Jakarta: PT. Gramedia Pustaka Utama

Skytrax, (2018). Airport \& Airline Rating. www.airlinequality.com. Diakses pada 5 Maret 2018. 
E-Jurnal Manajemen, Vol. 8, No. 1, 2019: 7519 - 7547

Sugiyono.(2014). Metode Penelitian Kuantitatif Kualitatif \& RND. Bandung : Alfabeta

Sumarwan, U., Retnaningsih, dan Fitriyana, H.R. (2010). Analisis Ekuitas Merek Laptop Pada Mahasiswa Institut Pertanian Bogor. Jurnal Ilmu Keluargadan Konsumen, 3 (2), Hal. 190-196.

Widjaja, M., Wijaya, S. dan Jokom, R. (2007). Analisis Penilaian Konsumen Terhadap Ekuitas Merek Coffee Shop di Surabaya. Jurnal ManajemenPerhotelan, 3(2). Hal. 89-101. 